\title{
THE USE OF Pb-210 ISOTOPE AS AN INDICATOR OF POLLUTANTS' MIGRATION IN THE ENVIRONMENT
}

\author{
WYKORZYSTANIE IZOTOPU Pb-210 JAKO WSKAŹNIKA \\ PRZEMIESZCZANIA SIĘ ZANIECZYSZCZEŃ W ŚRODOWISKU
}

\begin{abstract}
Radioactive isotopes, both natural and artificial, present in the environment, may be convenient indicators that can be used to study many physical and chemical processes as well as the transport of pollutants in the ecosystem. The studies have shown that in identification of particulate matter emission sources a radioactive lead isotope $(\mathrm{Pb}-210)$ can be used. The $\mathrm{Pb}-210$ increased activity concentration in the top soil layers suggests its current atmospheric deposition. This conclusion is confirmed by the results of the Principal Components Analysis, conducted using the measured radionuclide content in $0-30 \mathrm{~cm}$ deep soil layer samples.
\end{abstract}

Keywords: $\mathrm{Pb}-210$, pollutant emission indicator

\section{Introduction}

Radioactivity is not only a source of human exposure, but it also has many practical applications. Using the properties of radioactive isotopes, it is possible, for example, to generate electricity, test materials, diagnose and treat people. Radioisotopes are also used in environmental studies [1].

Radioactive isotopes are used, inter alia, to study the mechanisms and dynamics of the processes in soil and plants (eg K-40, P-32, Fe-59 and O-15), to determine the age of rocks, minerals, sediments and soil (eg C-14, U-238, U-235 and Th-232), to study the circulation of elements and their radioactive isotopes in the food chain (eg K-40, Cs-137, Sr-90, I-131, $\mathrm{Ca}-45$ and $\mathrm{P}-32$ ) and in the monitoring studies (natural isotopes, eg K-40, U-238, Pb-210, Po-210 and Ra-226, or artificial isotopes, eg P-32, Fe-59, Co-60, I-131, Cs-137, Sr-90 and Te-99) [1].

The examples of monitoring studies include the assessment of the activity of caesium isotopes in surface soil in spatial terms [2-5].

Radioactive isotopes are also used in laboratory testing of processes under controlled conditions, which makes it possible to describe them and to assess the behavior in the environment. The use of these methods is presented, inter alia, in sample Australian studies

\footnotetext{
${ }^{1}$ Independent Chair of Biotechnology and Molecular Biology, Opole University, ul. kard. B. Kominka 6, 45-035 Opole, Poland, phone +48 7740160 46, email: agna@ uni.opole.pl
} 
[6]. The use of Cs-134, Sr-85 and Zn-65 made it possible to determine the penetration of radioactive fallout into tropical soil. Cd-109, Co-60, Cr-51, Fe-59, Mn-54 and Zn-65 were used to identify the mechanism and dynamics of trace metal bonding in port sediments.

Radioactive isotopes present in the environment, such as Th-234, Be-7, Pb-210, Cs-137, Si-32 and C-14, were used to study present-day sedimentation in seas and oceans. Th-234 and Be-7 isotopes are used, inter alia, in bioturbation and sedimentation studies in the high material supply conditions [7, 8].

$\mathrm{Pb}-210$ isotope is most commonly used to determine the rate of marine [9] and lacustrine [10-14] sediment increase, but also to identify the rate of snow cover increase. The lead method was also used in Alpine glacier studies [15, 16].

Cs-137 is used, as a time marker, very often together with $\mathrm{Pb}-210$, to determine the age of lacustrine sediments. The literature review shows that Cs-137 may be used to determine the rate of deposition of overbank [17, 18], lacustrine and delta [19, 20] sediments. Cs-137 isotope is also used to assess soil erosion [21-28].

Ra-226 isotope is used to determine underground water zones, which contain more quantities of this isotope than surface water. Using this isotope, it is also possible to estimate the amount of outflowing underground water and its change in time and thus to estimate the extent of carrying pollutants, in particular nitrates, to coastal water by underground water. Taking into account Ra-226/Ra-228/Ra-224/Ra-223 isotope ratios, it is possible to determine the time underground water stays in reservoir rocks before it reaches sea water. The same isotopes may be used to determine the inflow of underground water from various reservoirs to surface water as well as to identify the zone where these components mix together [29].

Similarly, radon isotopes, including mainly Rn-222, are used to determine the inflow of underground water to surface water reservoirs, especially bay water. Rn-222 is also used to identify underground water inflow zones. This isotope is useful as a marker of the inflow of surface water into karst systems and the zones of the inflow of underground karst water into surface water. It is also used to measure the flow rate of underground water in fault zones and to determine the inflow of underground water from aquifers into a hydrogeological borehole.

Similarly, radon isotopes, including mainly Rn-222, are used to determine the inflow of underground water to surface water reservoirs, especially bay water. Rn-222 is also used to identify underground water inflow zones. This isotope is useful as a marker of the inflow of surface water into karst systems and the zones of the inflow of underground karst water into surface water. It is also used to measure the flow rate of underground water in fault zones and to determine the inflow of underground water from aquifers into a hydrogeological borehole.

The phenomenon of radioactivity of natural isotopes present in the Earth's crust was also used to determine the absolute (calendar) age of events occurring in nature, ie for the purpose of the so-called radiocarbon dating [30-32]. C-14 is commonly used as a marker in geology and archaeology. It makes it possible to determine the age of objects dating back to more than 40,000 years [33-36].

The content of radiocarbon $(\mathrm{C}-14)$ in soluble carbonates is used in water origin and age studies. Additionally, the $\mathrm{C}-13 / \mathrm{C}-12$ ratio is also measured. Other radioactive markers used to determine the age of water include $\mathrm{Kr}-85, \mathrm{Ar}-39, \mathrm{Cl}-36$ and $\mathrm{Kr}-81$ as well as the $\mathrm{U}-234 / \mathrm{U}-238$ ratio [1]. 
For dating the environment elements, the ratios of the activity of long-lived radionuclides, ie $\mathrm{U}-238 / \mathrm{Pb}-208, \mathrm{U}-235 / \mathrm{Pb}-207$ and $\mathrm{K}-40 / \mathrm{Ar}-40$, are also used. Thanks to them, it was possible, inter alia, to determine the age of the solar system and the Earth's crust. Using the Ar-39/Ar-40 and K-40/Ar-40 isotope ratios, it is possible to determine the age of rocks containing potassium minerals [37].

Be-7 cosmogenic isotope [38-42] and $\mathrm{Pb}-210$ isotope [43-45] are used to study the transport of aerosols in the atmosphere.

The lifetime of aerosols was estimated based on the Po-210/Pb-210 ratio [44-46].

The main objective of the studies was to assess the possibility of using lead isotope $(\mathrm{Pb}-210)$ as an indicator of pollutants' migration in the environment.

\section{Experimental}

In studies the soil samples were collected in 3 locations characterized by different properties. Samples of agricultural soil from Opole (south-western Poland), taken in allotments from the depth ranges $0-30 \mathrm{~cm}$, and crop field located in vicinity of lime stone works situated close to Tarnow Opolski town (south-west Poland, opolskie voivodeship), taken from the depth ranges $0-15 \mathrm{~cm}$ and $15-30 \mathrm{~cm}$, were used in the studies.

Additionally, samples of forest soil were taken from the $10 \mathrm{~cm}$ layer at 13 places in forests around Opole (south-western Poland) in an area of Bory Stobrawskie limited approximately by a $40 \mathrm{~km} \times 20 \mathrm{~km}$ rectangle.

The material for measurements was prepared in the following steps:

1. collection of subsamples from the area of approx. $100 \mathrm{~m}^{2}$,

2. impurities removal,

3. air drying, storage in paper bags,

4. drying at $105^{\circ} \mathrm{C}$ to constant mass,

5. mixing of subsamples, separation of subsample for measurement,

6. gamma spectrum measurement, subsample in Marinelli container $450 \mathrm{~cm}^{3}$.

The measurement of radionuclide activity in soils samples was carried out by means of a gamma-spectrometer with a germanium detector HPGe (Canberra) of high resolution: $1.29 \mathrm{keV}$ (FWHM) at $662 \mathrm{keV}$ and $1.70 \mathrm{keV}$ (FWHM) at $1332 \mathrm{keV}$. Relative efficiency: $21.7 \%$. Energy and efficiency calibration of the gamma spectrometer was performed with the standard solutions type MBSS 2 (Czech Metrological Institute, Praha), which covers an energy range from 59.54 to $1836.06 \mathrm{keV}$. The geometry of the calibration source was a Marinelli container $\left(447.7 \pm 4.5 \mathrm{~cm}^{3}\right)$, with density $0.99 \pm 0.01 \mathrm{~g} / \mathrm{cm}^{3}$, containing Am-241, Cd-109, Ce-139, Co-57, Co-60, Cs-137, Sn-113, Sr-85, Y-88 and Hg-203. The geometry of sample container was a similar Marinelli of $450 \mathrm{~cm}^{3}$. Time of measurement was $24 \mathrm{~h}$ for all of moss samples. Measuring process and analysis of spectra were computer controlled with the use of software GENIE 2000.

\section{Results and discussions}

In soil samples the following radionuclides were determined: K-40, Cs-137, Pb-210, Bi-212, Pb-212, Bi-214, Pb-214, Ac-228, Bi-211, Th-231 and U-235. The isotopes Pb-210, $\mathrm{Bi}-214$ and $\mathrm{Pb}-214$ are members of radium decay series. The Bi-212, $\mathrm{Pb}-212$ and $\mathrm{Ac}-228$ isotopes belong to thorium series, and actinium decay chain contains Bi-211, Th-231 and $\mathrm{U}-235$. The $\mathrm{K}-40$ radionuclide is constituent in natural potassium, with constant abundance 
of $0.017 \%$. This isotope is the main radioactivity source for organisms. The Cs-137 is an artificial radioisotope. It was introduced into environment with the global fallout, resulting from nuclear tests, particularly intensified in 1963-1964, as well as the nuclear power plants fallouts, for example Chernobyl 1986 [47] and Fukushima Daiichi 2011 [48]. Half-life times of these radioisotopes are shown in Table 1 [49].

Table 1

Half-life times of the radionuclides determined in soil samples

\begin{tabular}{|c|c|c|c|c|c|c|c|c|c|c|c|}
\hline Isotope & K-40 & Cs-137 & $\begin{array}{c}\text { Pb-210 } \\
*\end{array}$ & $\begin{array}{c}\text { Bi-212 } \\
* *\end{array}$ & $\begin{array}{c}\text { Pb-212 } \\
* *\end{array}$ & $\begin{array}{c}\text { Bi-214 } \\
*\end{array}$ & $\begin{array}{c}\text { Pb-214 } \\
*\end{array}$ & $\begin{array}{c}\text { Ac-228 } \\
* *\end{array}$ & $\begin{array}{c}\text { Bi-211 } \\
* * *\end{array}$ & $\begin{array}{c}\text { Th-231 } \\
* * *\end{array}$ & $\begin{array}{c}\text { U-235 } \\
* * *\end{array}$ \\
\hline \multirow{2}{*}{$t_{1 / 2}$} & $\begin{array}{c}1.248 \cdot 10^{9} \\
\mathrm{a}\end{array}$ & $\begin{array}{c}30.08 \\
\mathrm{a}\end{array}$ & $\begin{array}{c}22.2 \\
\mathrm{a}\end{array}$ & $\begin{array}{c}25 \\
\mathrm{~min}\end{array}$ & $\begin{array}{c}10.64 \\
\mathrm{~h}\end{array}$ & $\begin{array}{c}19.9 \\
\mathrm{~min}\end{array}$ & $\begin{array}{c}26.8 \\
\mathrm{~min}\end{array}$ & $\begin{array}{c}6.15 \\
\mathrm{~h}\end{array}$ & $\begin{array}{c}2.14 \\
\mathrm{~min}\end{array}$ & $\begin{array}{c}25.52 \\
\mathrm{~h}\end{array}$ & $\begin{array}{c}7.04 \cdot 10^{8} \\
\mathrm{a}\end{array}$ \\
\hline
\end{tabular}

* - radium series, $* *$ - thorium series, $* * *$ - actinium series

a)

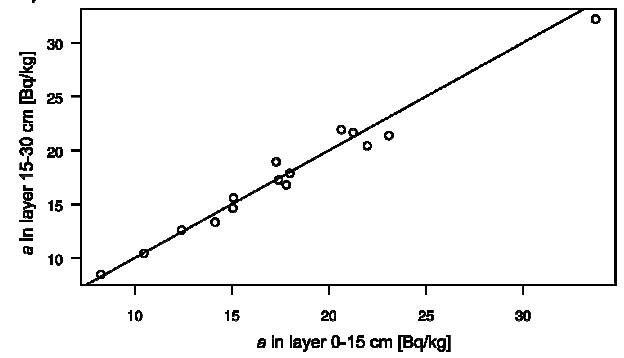

c)

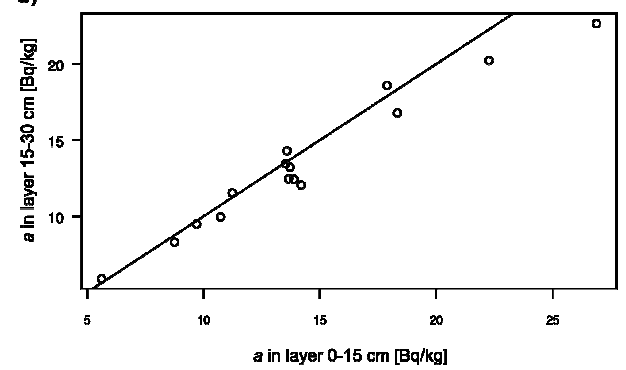

e)

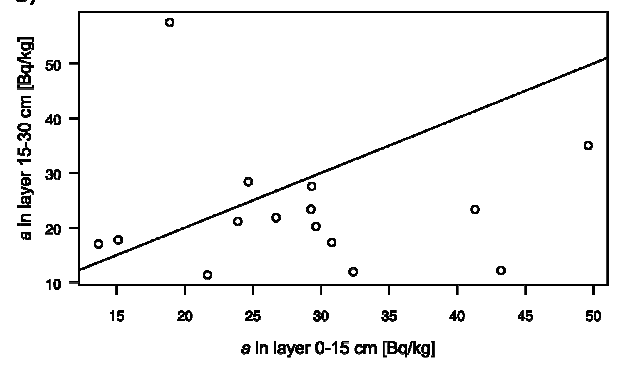

b)

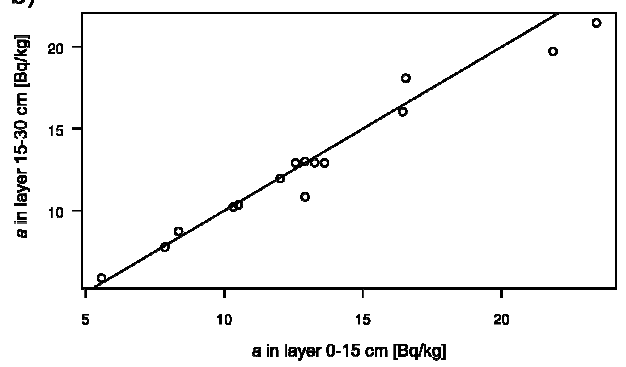

d)

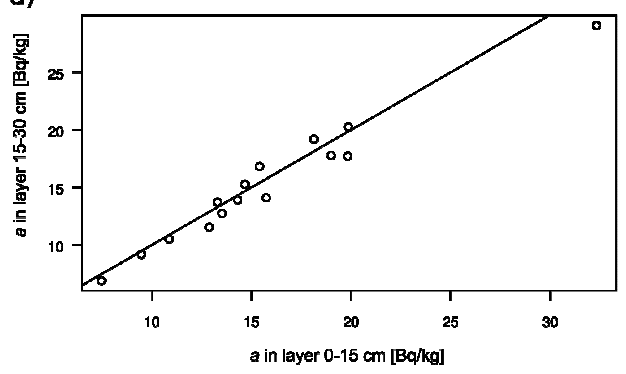

Fig. 1. Relationship between the activity concentrations of radionuclides in upper and lower soil layer: a) for $\mathrm{Ac}-228$; b) for $\mathrm{Bi}-214$; c) for $\mathrm{Pb}-214$; d) for $\mathrm{Pb}-212$ and e) for $\mathrm{Pb}-210$ 
Soil samples were collected from the crop field located in vicinity of lime stone works situated close to Tarnow Opolski. During seasonal agricultural operations (for example, ploughing or harrowing) and crop collection the soil surface is disturbed. The most upper layers and the ones located somewhat deeper are mixed together and their actual composition is expected to become similar. This expectation was verified by comparison of radionuclides activity concentration in 0-15 cm layer and the deeper, $15-30 \mathrm{~cm}$ layer. The relationship are shown in the graphs (Fig. 1). In these figures the straight line shows equal values of the radionuclide activity concentrations in both layers.

The obtained measurement results showed that the activity concentrations of majority of natural radioactive isotopes, in lower and upper soil layers, were close to 1 . The situation is different in the case of $\mathrm{Pb}-210$ whose increased activity is observed in the surface soil layers.

Given that the studies were conducted on arable soil, the presented data suggest current atmospheric deposition of this radionuclide.

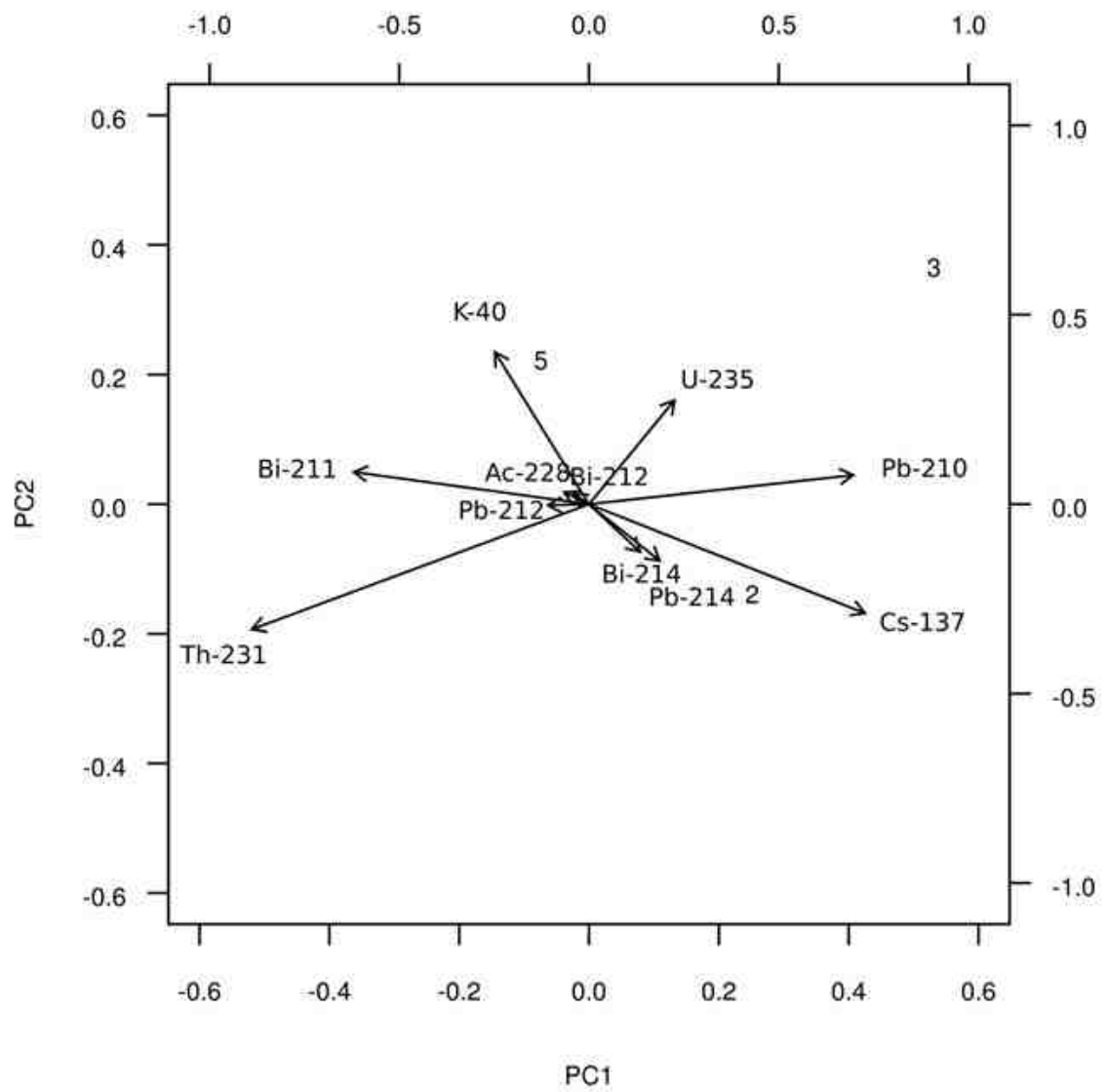

Fig. 2. Variables factor map of principal components calculated from clr transformed isotope concentrations 
Relationships between mass concentrations of radioisotopes in 0-30 cm soil layer samples, collected in allotments, were studied. For this purpose, the compositional data analysis methods were utilized [50, 51]. The principal components analysis (PCA) [52, 53], confirmed different behavior of $\mathrm{Pb}-210$ as compared to other radioactive isotopes determined (Fig. 2).

The Figure 2 shows the share of the activity of the main components and the position of points in a coordinate system, created by PC1 and PC2. The calculations were made based on the complex variable components transformed by transformation of centered logratio, clr [50].

The analysis of the biplot shows that interrelations occur between isotopes from the same radioactive series. Absence of radioactive equilibrium among isotopes from uranium-actinium series (U-235, Th-231 and Bi-211) was observed. This observation might be due to significant measurement uncertainty, estimated for these radioisotopes activity concentrations, in comparison to the results obtained for other radioisotopes.

The exception is also $\mathrm{Pb}-210$, which content was not related to content of other isotopes from the uranium-radium series.

Different behavior of $\mathrm{Pb}-210$ suggests the presence of two, autogenic and allogenic, components of this isotope in the environment. The autogenic component is closely associated with $\mathrm{Ra}-226$ isotope and the allogenic component with excess $\mathrm{Pb}$.

The presence of two lead components makes it possible to calculate excess lead (formula (1)) which was used to determine emission sources in Bory Stobrawskie area:

$$
\alpha_{P b e x}=\alpha_{P b-210}-\alpha_{R a-226}
$$

where $a$ - the activity of a given isotope in soil [Bq $/ \mathrm{kg}$ d.m.].

The activity of Ra-226 was calculated based on the known activities of $\mathrm{Pb}-214$ and Bi-214:

$$
\alpha_{R a-226}=\frac{\alpha_{P b-214}+\alpha_{B i-214}}{2}
$$

The results of $\mathrm{Pb}_{\mathrm{ex}}$ activity concentrations in soil samples in the Bory Stobrawskie area are given in Table 2. In this table Min is the lowest value in data, $Q 1$ is lower quartile, Median is median, Mean is arithmetic mean, $Q 3$ is upper quartile, Max is the highest value, $C V$ is variability of coefficient.

Characteristics of $\mathrm{Pb}_{\mathrm{ex}}$ activity concentrations in dry mass of the soils samples collected

\begin{tabular}{|c|c|c|c|c|c|c|c|}
\hline & \multicolumn{7}{|c|}{$\mathbf{P b}_{\mathrm{ex}}$ radioactivity concentration } \\
\hline & Min & $Q 1$ & Median & Mean & $Q 3$ & $\operatorname{Max}$ & $\mathrm{CV}$ \\
\hline & \multicolumn{6}{|c|}{ [Bq/kg d.m.] } & {$[\%]$} \\
\hline Soil & 12.1 & 24.9 & 44.3 & 69.5 & 109 & 164 & 0.8 \\
\hline
\end{tabular}
in the Bory Stobrawskie area

The obtained $\mathrm{Pb}_{\mathrm{ex}}$ results characterised by the highest $\mathrm{Pb}_{\mathrm{ex}}$ activity levels (above $100 \mathrm{~Bq} / \mathrm{kg} \mathrm{d.m.)} \mathrm{are} \mathrm{shown} \mathrm{on} \mathrm{Bory} \mathrm{Stobrawskie} \mathrm{map} \mathrm{(Fig.} \mathrm{3).}$

The data shown on the map is consistent with the results presented in the paper [54], in which passive biomonitoring with $\mathrm{Pb}-210$ was used to assess the deposition of pollutants. 


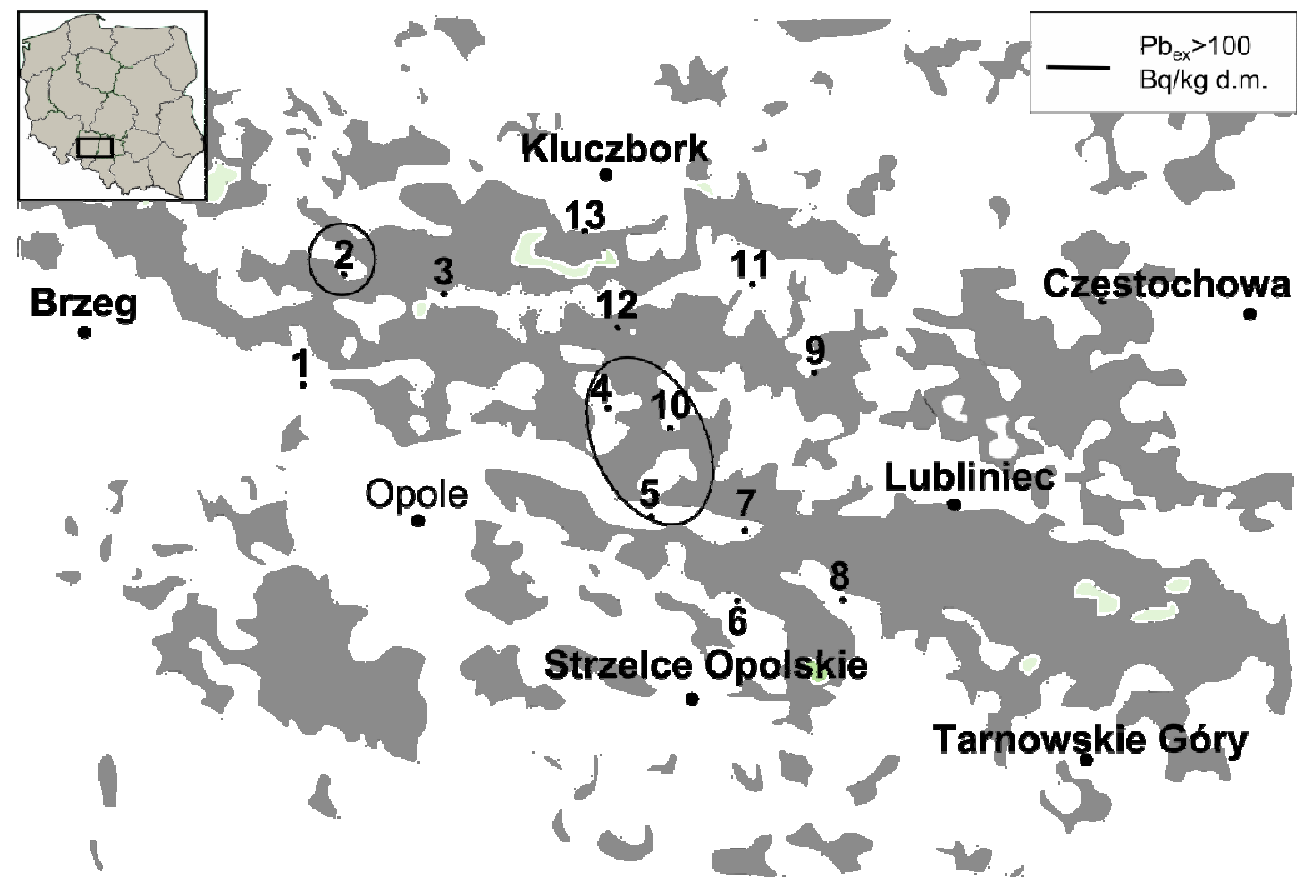

Fig. 3. The map showing $\mathrm{Pb}_{\mathrm{ex}}$ deposition sites in the study area

The presented data demonstrate that allogenic $\mathrm{Pb}-210$ may be used as a marker of environmental pollution and in places where its activity is increased one may expect pollutants associated, inter alia, with the local industry.

\section{Conclusions}

- In the arable soil, in the layers close to its surface, the activities of radioactive isotopes, not deposited additionally in the environment, are similar to each other. The situation is different in the case of $\mathrm{Pb}-210$ whose increased activity is observed in the surface soil layers. It suggests current atmospheric deposition of this radionuclide. This conclusion is confirmed by the results of PCA, conducted using the measured radionuclide content in 0-30 $\mathrm{cm}$ deep soil layer samples.

- The studies have shown that it is possible to identify particular matter emission sources using a radioactive lead isotope $(\mathrm{Pb}-210)$.

- Allogenic Pb-210 may be used as a marker of environmental pollution and in places where its activity is increased one may expect pollutants associated, inter alia, with the local industry.

\section{Acknowledgments}

The project was financed by the National Science Centre, based on decision number DEC-2011/03/D/ ST10/05392. 


\section{References}

[1] Dołhańczuk-Śródka A, Ziembik Z, Kusza G. Wykorzystanie metod statystycznych do opisu migracji izotopów promieniotwórczych w środowisku przyrodniczym. (The use of statistical methods to describe the migration of radionuclides in the environment). Warszawa: WNT; 2015.

[2] Kubica B, Szarlowicz K, Stobinski M, Skiba S, Reczynski W, Gołas J. Concentrations of ${ }^{137}$ Cs and ${ }^{40} \mathrm{~K}$ radionuclides and some heavy metals in soil samples from the eastern part of the Main Ridge of the Flysch Carpathians. J Radioanal Nucl Chem. 2014;299(3):1313-1320. DOI: 10.1007/s10967-013-2890-3.

[3] Szabó KZ, Udvardi B, Horváth Á, Bakacsi Z, Pásztor L, Szabó J, et al. Cesium-137 concentration of soils in Pest County, Hungary. J Environ Radioact. 2012;110:38-45. DOI: 10.1016/j.jenvrad.2012.01.023.

[4] Dołhańczuk-Śródka A, Majcherczyk T, Smuda M, Ziembik Z, Wacławek M. Spatial ${ }^{137}$ Cs distribution in forest soil. Nukleonika. 2006;51(2):S69-S79. http://www.ichtj.waw.pl/ichtj/nukleon/back/ full/vol51_2006/v51s2p69f.pdf.

[5] Kubica B, Skiba S, Drewnik M, Stobiński M, Kubica M, Golas J, et al. Radionuclides Cs-137 and K-40 in the soils of the Tatra National Park (TPN, Poland). Nukleonika. 2010;55(3):377-386. http://www.nukleonika.pl/www/back/full/vol55_2010/v55n3p377f.pdf,

[6] Payne T., Hatje V, Itakura T, McOrist G, Russell R. Radionuclide applications in laboratory studies of environmental surface reactions. J Environ Radioact. 2004;76(1-2):237-251. DOI: 10.1016/j.jenvrad.2004.03.029.

[7] Lecroart P, Maire O, Schmidt S, Grémare A, Abrahams PW, Meysman FJR. Bioturbation, short-lived radioisotopes, and the tracer-dependence of biodiffusion coefficients. Geochim Cosmochim Acta. 2010;74(21):6049-6063. DOI: 10.1016/j.gca.2010.06.010.

[8] Medich DC, Abayomi K, Boudreau BP, Meysman FJR. Steady-state tracer dynamics in a lattice-automaton model of bioturbation. Geochim Cosmochim Acta. 2006;70(23):5855-5867. DOI: 10.1016/j.gca.2006.03.026.

[9] Johannessen SC, Macdonald RW. There is no 1954 in that core! Interpreting sedimentation rates and contaminant trends in marine sediment cores. Mar Pollut Bull. 2012;64(4):675-678. DOI: 10.1016/j.marpolbul.2012.01.026.

[10] Xue B, Yao S. Recent sedimentation rates in lakes in lower Yangtze River basin. Quat Int. 2011;244(2):248-253. DOI: 10.1016/j.quaint.2011.01.003.

[11] Xu L, Wu F, Wan G, Liao H, Zhao X, Xing B. Relationship between ${ }^{210} \mathrm{~Pb}_{\mathrm{ex}}$ activity and sedimentary organic carbon in sediments of 3 Chinese lakes. Environ Pollut. 2011;159(12):3462-3467. DOI: 10.1016/j.envpol.2011.08.020.

[12] Barlas Simsek F, Cagatay MN. Geochronology of lake sediments using ${ }^{210} \mathrm{~Pb}$ with double energetic window method by LSC: An application to Lake Van. Appl Radiat Isot. 2014;93:126-133. DOI: 10.1016/j.apradiso.2014.01.028.

[13] Szarlowicz K, Kubica B. ${ }^{137} \mathrm{Cs}$ and ${ }^{210} \mathrm{~Pb}$ radionuclides in open and closed water ecosystems. J Radioanal Nucl Chem. 2014;299(3):1321-1328. DOI: 10.1007/s10967-013-2864-5.

[14] Szarłowicz K, Reczyński W, Golas J, Kościelniak P, Skiba M, Kubica B. Sorption of Cs-137 and Pb on sediment samples from a drinking water reservoir. Pol J Environ Stud. 2011;20(5):1305-1312. http://www.pjoes.com/pdf/20.5/Pol.J.Environ.Stud.Vol.20.No.5.1305-1312.pdf.

[15] Gäggeler H, Gunter HR, Rössler E, Oeschger H, Schotterrer U. ${ }^{210} \mathrm{~Pb}$ - dating of cold Alpine firn/ice cores from Colle Gnifetti, Switzerland. J Glaciol. 1983;29:165-177. http://www.igsoc.org:8080/ journal/29/101/igs_journal_vol29_issue101_pg165-177.pdf.

[16] von Gunten HR, Moser RN. How reliable is the ${ }^{210} \mathrm{~Pb}$ dating method? Old and new results from Switzerland. J Paleolimnol. 1993;9(2):161-178. DOI: 10.1007/BF00677518.

[17] Walling DE, He Q. Use of fallout ${ }^{137} \mathrm{Cs}$ in investigations of overbank sediment deposition on river floodplains. CATENA. 1997;29(3-4):263-282. DOI: 10.1016/S0341-8162(96)00072-0.

[18] Walling D., He Q. The spatial variability of overbank sedimentation on river floodplains. Geomorphology. 1998;24(2-3):209-23. DOI: 10.1016/S0169-555X(98)00017-8.

[19] Zhang X, Walling DE. Characterizing land surface erosion from cesium-137 profiles in lake and reservoir sediments. J Environ Qual. 2005;34(2):514-523. DOI: 10.2134/jeq2005.0514.

[20] Ueda S, Ohtsuka Y, Kondo K, Hisamatsu S. Inventories of ${ }^{239+240} \mathrm{Pu}$, ${ }^{137} \mathrm{Cs}$, and excess ${ }^{210} \mathrm{~Pb}$ in sediments from freshwater and brackish lakes in Rokkasho, Japan, adjacent to a spent nuclear fuel reprocessing plant. J Environ Radioact. 2009;100(10):835-840. DOI: 10.1016/j.jenvrad.2009.06.008. 
[21] An J, Zheng F, Wang B. Using 137Cs technique to investigate the spatial distribution of erosion and deposition regimes for a small catchment in the black soil region, Northeast China. CATENA. 2014;123:243-251. DOI: 10.1016/j.catena.2014.08.009.

[22] Zhang X, Long Y, He X, Fu J, Zhang Y. A simplified ${ }^{137}$ Cs transport model for estimating erosion rates in undisturbed soil. J Environ Radioact. 2008;99(8):1242-1246. DOI: 10.1016/j.jenvrad.2008.03.001.

[23] Zhang CL, Yang S, Pan XH, Zhang JQ. Estimation of farmland soil wind erosion using RTK GPS measurements and the ${ }^{137} \mathrm{Cs}$ technique: A case study in Kangbao County, Hebei province, northern China. Soil Tillage Res. 2011;112(2):140-148. DOI: 10.1016/j.still.2010.12.003.

[24] Benmansour M, Mabit L, Nouira A, Moussadek R, Bouksirate H, Duchemin M, et al. Assessment of soil erosion and deposition rates in a Moroccan agricultural field using fallout ${ }^{137} \mathrm{Cs}$ and ${ }^{210} \mathrm{Pbex}$. J Environ Radioact. 2013;115:97-106. DOI: 10.1016/j.jenvrad.2012.07.013.

[25] Kirchner G. Establishing reference inventories of ${ }^{137} \mathrm{Cs}$ for soil erosion studies: Methodological aspects. Geoderma. 2013;211-212:107-115. DOI: 10.1016/j.geoderma.2013.07.011

[26] Menéndez-Duarte R, Fernández S, Soto J. The application of ${ }^{137} \mathrm{Cs}$ to post-fire erosion in north-west Spain. Geoderma. 2009;150(1-2):54-63. DOI: 10.1016/j.geoderma.2009.01.012.

[27] Ritchie JC, McHenry JR. Application of radioactive fallout cesium-137 for measuring soil erosion and sediment accumulation rates and patterns: A review. J Environ Qual. 1990;19(2):215. DOI: 10.2134/jeq1990.00472425001900020006x.

[28] Porȩba GJ, Bluszcz A. Influence of the parameters of models used to calculate soil erosion based on ${ }^{137} \mathrm{Cs}$ tracer. Geochronometria. 2009;32(1):21-27. http://www.geochronometria.pl/pdf/geo_32/Geo32_03.pdf.

[29] Kelly RP, Moran SB. Seasonal changes in groundwater input to a well-mixed estuary estimated using radium isotopes and implications for coastal nutrient budgets. Limnol Oceanogr. 2002;47(6):1796-1807. http://aslo.info/lo/toc/vol_47/issue_6/1796.pdf.

[30] Patrut A, von Reden KF, Van Pelt R, Mayne DH, Lowy DA, Margineanu D. Age determination of large live trees with inner cavities: radiocarbon dating of Platland tree, a giant African baobab. Ann For Sci. 2011;68(5):993-1003. DOI: 10.1007/s13595-011-0107-x.

[31] Kolár T, Rybníček M. Dendrochronological and radiocarbon dating of subfossil wood from the Morava River basin. Geochronometria. 2011;38(2):155-161. DOI: 10.2478/s13386-011-0021-x.

[32] Zazzo A, Saliège JF. Radiocarbon dating of biological apatites: A review. Palaeogeogr Palaeoclimatol Palaeoecol. 2011;310(1-2):52-61. DOI: 10.1016/j.palaeo.2010.12.004.

[33] Terry M, Steelman KL, Guilderson T, Dering P, Rowe MW. Lower Pecos and Coahuila peyote: new radiocarbon dates. J Archaeol Sci. 2006;33(7):1017-1021. DOI: 10.1016/j.jas.2005.11.008.

[34] Richter D, Tostevin G, Škrdla P, Davies W. New radiometric ages for the Early Upper Palaeolithic type locality of Brno-Bohunice (Czech Republic): comparison of OSL, IRSL, TL and 14C dating results. J Archaeol Sci. 2009;36(3):708-720. DOI: 10.1016/j.jas.2008.10.017.

[35] Jöris O, Street M. At the end of the ${ }^{14} \mathrm{C}$ time scale-the Middle to Upper Paleolithic record of western Eurasia. J Hum Evol. 2008;55(5):782-802. DOI: 10.1016/j.jhevol.2008.04.002.

[36] Boaretto E, Poduska KM. Materials science challenges in radiocarbon dating: the case of archaeological plasters. JOM. 2013;65(4):481-488. DOI: 10.1007/s11837-013-0573-8.

[37] Clauer N. The K-Ar and 40Ar/39Ar methods revisited for dating fine-grained K-bearing clay minerals. Chem Geol. 2013;354:163-185. DOI: 10.1016/j.chemgeo.2013.05.030.

[38] Piñero García F, Ferro García MA, Azahra M. ${ }^{7}$ Be behaviour in the atmosphere of the city of Granada January 2005 to December 2009. Atmos Environ. 2012;47:84-91. DOI: 10.1016/j.atmosenv.2011.11.034.

[39] Dueñas C, Fernández MC, Cañete $\mathrm{S}$, Pérez M. ${ }^{7} \mathrm{Be}$ to ${ }^{210} \mathrm{~Pb}$ concentration ratio in ground level air in Málaga $\left(36.7^{\circ} \mathrm{N}, 4.5^{\circ} \mathrm{W}\right)$. Atmospheric Res. 2009;92(1):49-57. DOI: 10.1016/j.atmosres.2008.08.012.

[40] Yoshimori M. Beryllium 7 radionucleide as a tracer of vertical air mass transport in the troposphere. Adv Space Res. 2005;36(5):828-832. DOI: 10.1016/j.asr.2005.04.088.

[41] Pacini AA, Usoskin IG, Evangelista H, Echer E, de Paula R. Cosmogenic isotope ${ }^{7}$ Be: A case study of depositional processes in Rio de Janeiro in 2008-2009. Adv Space Res. 2011;48(5):811-818. DOI: 10.1016/j.asr.2011.04.035.

[42] Leppänen A-P, Pacini AA, Usoskin IG, Aldahan A, Echer E, Evangelista H, et al. Cosmogenic ${ }^{7}$ Be in air: A complex mixture of production and transport. J Atmospheric Sol-Terr Phys. 2010;72(13):1036-1043. DOI: 10.1016/j.jastp.2010.06.006.

[43] Lozano RL, Hernández-Ceballos MA, Rodrigo JF, San Miguel EG, Casas-Ruiz M, García-Tenorio R, et al. Mesoscale behavior of ${ }^{7} \mathrm{Be}$ and ${ }^{210} \mathrm{~Pb}$ in superficial air along the Gulf of Cadiz (south of Iberian Peninsula). Atmos Environ. 2013;80:75-84. DOI: 10.1016/j.atmosenv.2013.07.050. 
[44] Baskaran M. Po-210 and Pb-210 as atmospheric tracers and global atmospheric Pb-210 fallout: A review. J Environ Radioact. 2011;102(5):500-513. DOI: 10.1016/j.jenvrad.2010.10.007.

[45] Dueñas C, Fernández MC, Carretero J, Liger E, Cañete S. Deposition velocities and washout ratios on a coastal site (southeastern Spain) calculated from ${ }^{7} \mathrm{Be}$ and ${ }^{210} \mathrm{~Pb}$ measurements. Atmos Environ. 2005;39(36):6897-6908. DOI: 10.1016/j.atmosenv.2005.08.008.

[46] Papastefanou C. Residence time of tropospheric aerosols in association with radioactive nuclides. Appl Radiat Isot. 2006;64(1):93-100. DOI: 10.1016/j.apradiso.2005.07.006.

[47] Almgren S, Isaksson M. Vertical migration studies of ${ }^{137} \mathrm{cs}$ from nuclear weapons fallout and the Chernobyl accident. J Environ Radioact. 2006;91(1-2):90-102. DOI: 10.1016/j.jenvrad.2006.08.008.

[48] Hiroaki K, Onda Y, Teramage M. Depth Distribution of ${ }^{137} \mathrm{Cs},{ }^{134} \mathrm{Cs}$, and ${ }^{131} \mathrm{I}$ in soil profile after Fukushima Dai-Ichi Nuclear Power Plant accident. J Environ Radioact. 2012;111:59-64. DOI: 10.1016/j.jenvrad.2011.10.003.

[49] BNL. National Nuclear Data Center. 2014. http://www.nndc.bnl.gov/.

[50] Aitchison J. The Statistical Analysis of Compositional Data. Caldwell, New Yersey: The Blackburn Press, 2003.

[51] Pawlowsky-Glahn V, Buccianti A. Compositional Data Analysis. Theory and Applications. United Kingdom: John Wiley \& Sons, Ltd. 2011.

[52] Aitchison J, Greenacre M. Biplots of Compositional Data. J R Stat Soc: Series C (Appl Stat). 2002;51(4):375-92. DOI: 10.1111/1467-9876.00275.

[53] Filzmoser P, Hron K, Reimann C. Principal component analysis for compositional data with outliers. Environmetrics. 2009;20(6):621-632. DOI: 10.1002/env.966.

[54] Dołhańczuk-Śródka A, Ziembik Z, Kříž J, Hyšplerova L, Wacławek M. Pb-210 Isotope as a pollutant emission indicator. Ecol Chem Eng S. 2015;22(1):73-81. DOI: 10.1515/eces-2015-0004.

\title{
WYKORZYSTANIE IZOTOPU Pb-210 JAKO WSKAŹNIKA PRZEMIESZCZANIA SIĘ ZANIECZYSZCZEŃ W ŚRODOWISKU
}

\author{
Samodzielna Katedra Biotechnologii i Biologii Molekularnej, Uniwersytet Opolski
}

\begin{abstract}
Abstrakt: Izotopy promieniotwórcze, zarówno naturalne, jak i sztuczne, obecne w środowisku mogą być wygodnymi wskaźniki, które mogą być wykorzystane do badania wielu procesów fizykochemicznych oraz transportu zanieczyszczeń w ekosystemie. Podczas badań stwierdzono, że możliwa jest identyfikacja źródeł emisji pyłu przy wykorzystaniu radioaktywnego izotopu ołowiu - Pb-210, którego zwiększone aktywności obserwuje się w wierzchnich warstwach gleby. Wskazuje to na bieżącą, atmosferyczną depozycję tego radionuklidu. Wniosek ten potwierdzają wyniki analizy głównych składowych, wykonanej z wykorzystaniem zmierzonych zawartości radionuklidów w próbkach gleby w warstwie $0-30 \mathrm{~cm}$.
\end{abstract}

Słowa kluczowe: Pb-210, wskaźnik emisji zanieczyszczeń 